\title{
Effect of closed circuit television on urban violence
}

\author{
V Sivarajasingam, J P Shepherd
}

\begin{abstract}
Objective-To evaluate the effect of city and town centre closed circuit television (CCTV) surveillance on violence in terms of accident and emergency (A\&E) department and police assault data.

Methods-A\&E department and local police assault data in three centres in Wales (Cardiff, Swansea, and Rhyl) two years before and two years after the installation of CCTV were studied. British Crime Survey and police crime statistics were used as control data.

Results-A\&E records of 24442 assault patients and 3228 violent offences recorded by the police were studied. Data from two A\&E departments (Swansea $(+3 \%)$ and Rhyl (+45\%)) showed increases in recorded assaults after CCTV installation but a decrease $(12 \%)$ in the largest centre, Cardiff. There was an overall reduction in town/city centre violence from the $A \& E$ department perspective of $1 \%$ in the two years after CCTV installation. In contrast, police data demonstrated changes in the opposite direction $(-44 \%,-24 \%$, and $+20 \%$ respectively) contributing to an overall decrease of $9 \%$. British Crime Survey and police statistics for England and Wales demonstrated no overall change and a $16 \%$ increase respectively.

Conclusion-City centre CCTV installation had no obvious influence on levels of assaults recorded in A\&E departments. There was a negative relationship between police and $A \& E$ recording in all three centres. A\&E departments are important and unique sources of information about community violence.

(F Accid Emerg Med 1999;16:255-257)
\end{abstract}

Violence Research Group, University of Wales College of Medicine, Cardiff V Sivarajasingam J P Shepherd

Correspondence to: Professor Jonathan P Shepherd, Department of Oral Surgery, Medicine and Pathology, University of Wales College of Medicine, Dental School, Heath Park, Cardiff CF4 4XY.
Keywords: assault; injury prevention; epidemiology; closed circuit television

Rates of violence in England and Wales are among the highest in the world according to the International Victimisation Survey. ${ }^{1}$ Furthermore, a total of 344300 violent offences were recorded by the police in 1996 in England and Wales, an increase of 33400 (11\%) compared with $1995 .^{2}$ This was the largest annual increase in recorded crime since 1989. The major offence category was violence against the person, which accounted for $69 \%$ of all recorded violent crime. Increases in violence are also demonstrated by successive Home Office British Crime Surveys, ${ }^{23}$ which are two yearly surveys of large random samples of householders. The most recent British Crime Survey however, relating to crime in 1997 , demonstrated a $17 \%$ decrease in violent offences compared with 1995 - suggesting that the true assault rate may have peaked and is now falling. ${ }^{4}$ For both sexes, those in the 16-24 year old age group are most often offenders. ${ }^{5}$ Violence has become a major public health issue on both sides of the Atlantic. ${ }^{6}$

To prevent theft, burglary, and violence there has recently been rapid expansion in the installation of closed circuit television (CCTV) in towns and cities, facilitated by substantial local authority and government funding. ${ }^{7}$ Although there is convincing evidence that CCTV is effective in preventing acquisitive crime, like theft and car crime ${ }^{7}$ its effect on violent crime is not clear. We therefore investigated the effect of CCTV surveillance on urban violence from the perspective of accident and emergency (A\&E) department and police assault records. The principal hypothesis was that CCTV in city centres helps to prevent violence.

\section{Methods}

Three centres-Cardiff ( 25 cameras), Swansea (59 cameras), and Rhyl (36 cameras)-were included in the study. These are two cities and a town in Wales with well defined centres each served by a single A\&E department (Cardiff Royal Infirmary, Morriston Hospital, Swansea, and Glan Clwyd Hospital, Rhyl). All had CCTV installed and operational between December 1994 and January 1996. Violence data (common law assault, assault occasioning bodily harm, and wounding) from police divisions responsible for city centre policing in Cardiff, Swansea, and in Rhyl and A\&E department assault data were collected prospectively in the three centres, starting two years before CCTV installation and ending two years afterwards. Results were compared with two main measures of violence in Wales: the British Crime Survey and official police crime statistics. $^{23}$

In all three centres, there is 24 hour surveillance, though this is done by the police in Cardiff and Rhyl and by the local authority in Swansea, with provision for relay to the police when required. We looked for differences between immediate and longer term (first and 
Table 1 Number of assaults recorded before and after CCTV installation

\begin{tabular}{|c|c|c|c|c|c|c|c|c|}
\hline & \multicolumn{2}{|c|}{$\begin{array}{l}\text { Swansea fanuary } 1993 \\
\text { to December } 1996\end{array}$} & \multicolumn{2}{|c|}{$\begin{array}{l}\text { Cardiff April } 1993 \\
\text { to March } 1997\end{array}$} & \multicolumn{2}{|c|}{$\begin{array}{l}\text { Rhyl fanuary } 1994 \\
\text { to December } 1997\end{array}$} & \multicolumn{2}{|l|}{ Totals } \\
\hline & $A \mathcal{G} E$ & Police & $A \mathcal{E} E$ & Police & $A \mathcal{E} E$ & Police & $A \mathcal{E}^{\circ} E$ & Police \\
\hline \multicolumn{9}{|c|}{ Before CCTV installation } \\
\hline Year 1 & 1911 & 226 & 3445 & 313 & 593 & 261 & 5949 & 800 \\
\hline Year 2 & 2056 & 260 & 3621 & 364 & 656 & 265 & 6333 & 889 \\
\hline Total & 3967 & 486 & 7066 & 677 & 1249 & 526 & 12282 & 1689 \\
\hline \multicolumn{9}{|c|}{ After CCTV installation } \\
\hline Year 3 & 2149 & 162 & 3188 & 385 & 830 & 205 & 6167 & 752 \\
\hline Year 4 & 1937 & 159 & 3063. & 433 & 993 & 195 & 5993 & 787 \\
\hline Total & 4086 & 321 & 6251 & 818 & 1823 & 400 & 12160 & 1539 \\
\hline$\%$ Change & +3 & -44 & -12 & +20 & +45 & -24 & -1 & -9 \\
\hline \multicolumn{9}{|c|}{ (years $1+2$ compared with years $3+4$ ) } \\
\hline \multicolumn{9}{|c|}{ Summer months (Fuly to September) } \\
\hline \multicolumn{9}{|c|}{ Before CCTV installation } \\
\hline Year 1 & 499 & 40 & 854 & 70 & 168 & 77 & 1521 & 187 \\
\hline Year 2 & 531 & 40 & 916 & 96 & 216 & 88 & 1663 & 224 \\
\hline Total & 1030 & 80 & 1770 & 166 & 384 & 165 & 3184 & 411 \\
\hline \multicolumn{9}{|c|}{ After CCTV installation } \\
\hline Year 3 & 562 & 42 & 945 & 98 & 235 & 60 & 1742 & 200 \\
\hline Year 4 & 528 & 41 & 749 & 101 & 298 & 57 & 1575 & 199 \\
\hline Total & 1090 & 83 & 1694 & 199 & 533 & 117 & 3317 & 399 \\
\hline $\begin{array}{l}\% \text { Change } \\
\text { (years } 1+2\end{array}$ & +6 & +4 & -4 & +20 & +39 & -29 & +4 & +3 \\
\hline
\end{tabular}

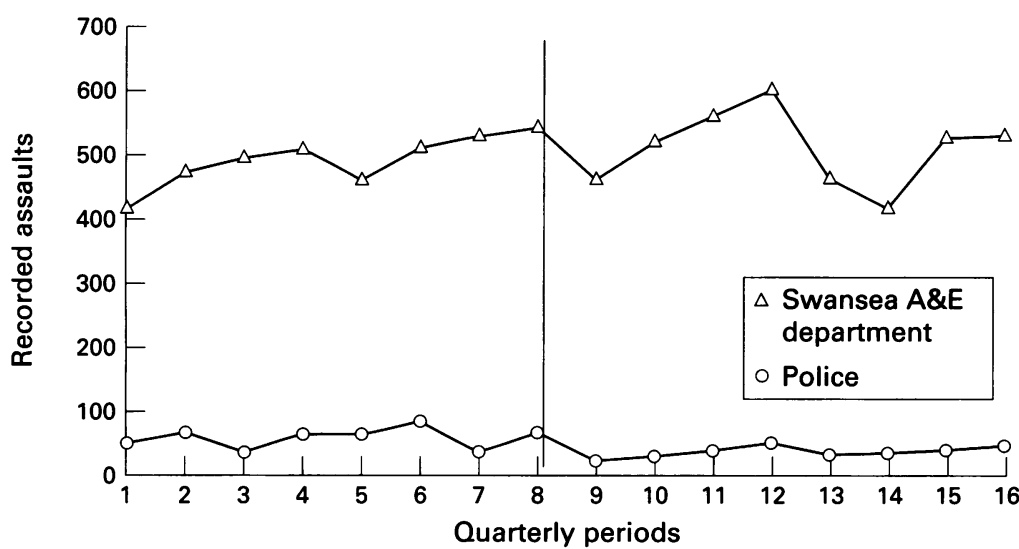

Figure 1 Swansea $A \mathcal{E} E$ and police quarterly assault data in the two years before and two years after installation of CCTV (vertical line).

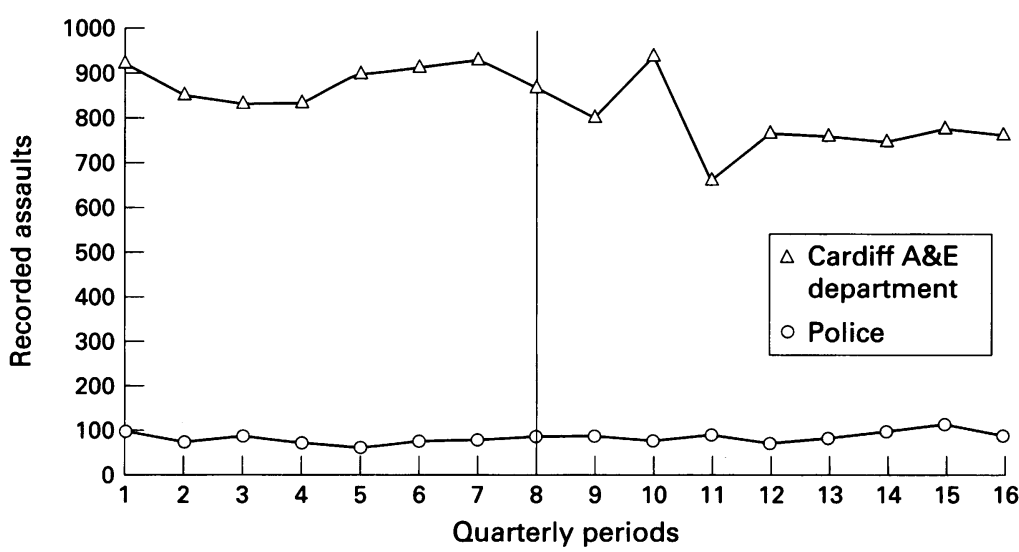

Figure 2 Cardiff $A \mathcal{E} E$ and police quarterly assault data in the two years before and two years after installation of CCTV (vertical line).

second year after CCTV installation) effects and seasonal differences that might include, for example, greater effects in the summer (July to September) when city centre streets are more crowded late at night.

\section{Results}

Table 1 shows the number of assaults recorded in $A \& E$ departments and by the police two years before and after CCTV installation. Overall, CCTV installation was associated with a $1 \%$ reduction in numbers of assaults recorded by $A \& E$ departments and a $9 \%$ reduction in assaults recorded by the police. Figures 1-3 show clearly that substantially greater numbers of assaults were recorded by the A\&E departments than the police: about threefold more in Rhyl, 10-fold more in Cardiff, and 10-fold more in Swansea, though in Cardiff and Swansea, data from police divisions outside the city centres were not included. Swansea and Rhyl police recorded fewer assaults (by about a third) after the installation of CCTV and Cardiff police recorded a $20 \%$ increase. In contrast, the $A \& E$ department in Swansea recorded about the same number whereas Cardiff A\&E department recorded $12 \%$ fewer assaults in the two years after CCTV installation. In the summer months (July to September) two A\&E departments (Swansea and Cardiff) and the police in Swansea recorded about the same number of people injured in assaults in the two years after CCTV installation while the A\&E department in Rhyl recorded $45 \%$ more. The police in Rhyl recorded a substantial decrease $(29 \%)$ in assaults in the summer. There was no evidence that CCTV surveillance had different early (first year) and late (second year) effects.

\section{Discussion}

There is no simple solution to the problem of violence related morbidity and mortality. This is in part because the causes of violence related injuries are multifactorial. Haddon in the 1960 s conceptualised injury as disease and subsequently developed a useful framework for the analysis of potential preventive measures. ${ }^{8}$ As with the epidemiological model for mitigating communicable disease, injury control can be achieved by altering the agent, eliminating the vector, changing host susceptibility, or modifying the environment.

Theoretically, installation and surveillance by means of CCTV would not only increase the risk of an offender being caught and therefore act as a deterrent, but also enhance the perception of the location as being safer in the public mind. As most violence is known to be 


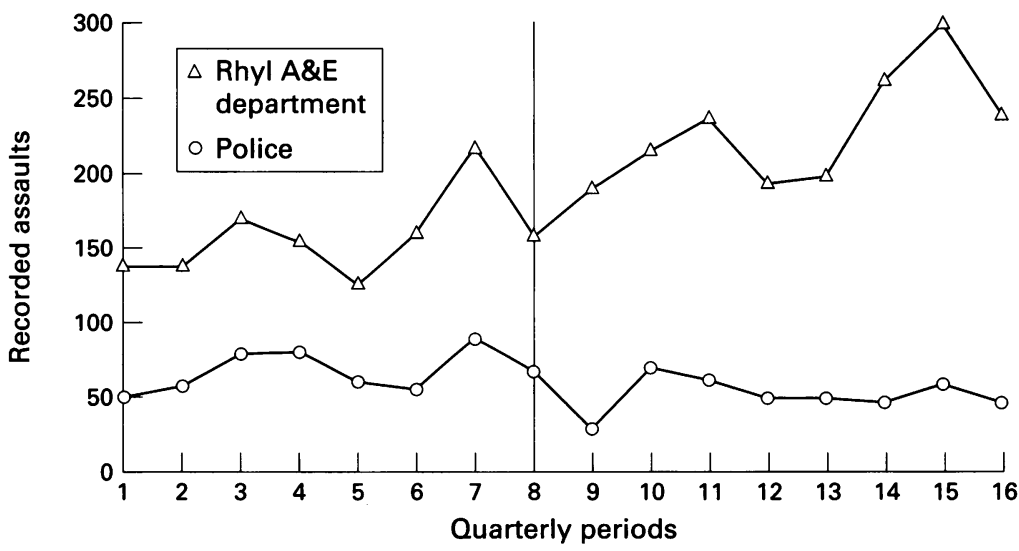

Figure $3 R$ Ryl $A \mathcal{E} E$ and police quarterly assault data in the two years before and two years after installation of CCTV (vertical line).

concentrated in relatively few streets within town and city centres, this study would have been expected to identify any clear changes in the incidence of violence consequent upon CCTV installation. Overall, $A \& E$ data do not suggest that CCTV installation reduced town/ city centre violence. Set against a background of no overall change in levels of violence in England and Wales according to British Crime Survey data (1993-95: 17\% increase; 199597: $17 \%$ decrease) and increases according to police data (1993-97: $16 \%$ increase), ${ }^{9}$ the substantial decrease in the number of people treated for injuries sustained in assaults in Cardiff stands out however. In terms of people injured in assaults recorded in particular $A \& E$ departments, there was an increase in only one centre, Rhyl, but a substantial decrease in assaults recorded by the police. This and the more substantial reductions in police recording in Swansea (44\%) might be explained in terms of displacement of some violence to locations not covered by CCTV such as licensed premises, where only about one in nine offences leading to $\mathrm{A} \& \mathrm{E}$ department treatment are recorded by the police, or outlying areas. ${ }^{10}$ This study provides no evidence of the differential temporal effects of CCTV which have been reported in relation to property crime. $^{7}$

Interestingly, in all three centres, there were opposite changes in the direction of effect when $A \& E$ and police data were compared. An increase in police recording was associated with a decrease in $A \& E$ recording and vice versa. This is consistent with the findings of large scale studies on the relationship between police recording and levels of violence according to doorstep crime surveys in the United States and England and Wales. ${ }^{11}$ Although the comparison of the results of large and small scale studies can be taken too far, it does support the idea that increasing rates of police recording can be effective in reducing commu- nity violence. In turn, this suggests that CCTV is not effective on its own but must be combined with strenuous police efforts to record the offences and prosecute the violent offenders which CCTV brings to light. In the context of the study reported here, perhaps the decreases in police recording in Swansea and Rhyl reflects a switch in resources away from methods which had resulted in recording before CCTV installation and over-reliance on CCTV. The CCTV study reported here indicates that $A \& E$ department derived data are an important and unique measure of community violence since $A \& E$ departments deal with the results of far more incidents than are being recorded by the police. This research also demonstrates that $\mathrm{A} \& \mathrm{E}$ computerised records do not include information about the circumstances of violence in most cases. There are therefore clear opportunities for collecting information about violence which would be of great importance to the local crime audits being carried out under the directions of the Crime and Disorder Act (1998). ${ }^{12}$ Health authorities are included in the act as bodies with whom local authorities and police authorities must collaborate to audit and tackle crime. In addition to measuring the effectiveness of CCTV, a slightly expanded A\&E assault data set would provide information which would be of substantial assistance in tackling crime in relation, for example, to measuring the effectiveness of measures designed to reduce violence which is known to be hidden from police surveillance, such as domestic violence and violence in licensed premises.

The authors thank A\&E staff and police officers in the three centres for advice and access to data, particularly Rupert Evan and Roy Simmons, Emergency Unit, Cardiff and Michael McCabe, Morriston Hospital, Swansea.

Conflict of interest: none.

Funding: none.

1 Mayhew P, White P. The 1996 international crime victimisation survey. Research findings. No 57. London: HMSO, 1996

2 Mirrlees-Black C, Mayhew P, Percy A. The British crime survey: England and Wales. London: HMSO, 1996.

3 Home Office. Police crime statistics (England and Wales) 1994-1996. London: HMSO, 1997.

4 Mirrlees-Black C, Budd T, Partridge S, et al. The British crime survey: England and Wales. London: HMSO, 1998.

5 Watson L. Victims of violent crime recorded by the police, England and Wales 1990-94. London: HMSO, 1996.

6 Shepherd JP. Tackling violence. BMF 1998;316:879.

6 Shepherd JP. Tackling violence. BMF 1998;316:879.

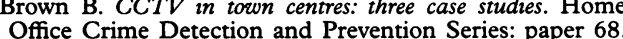
Office Crime Detection

London: HMSO, 1995.

8 Haddon W. Advances in the epidemiology of injuries as basis for public policy. Public Health Rep 1980;12:411.

9 Povey D, Prime J. Notifiable offences England and Wales, April 1997 to March 1998. Home Office Statistical Bulletin. London: HMSO, 1998.

10 Shepherd JP, Shapland M, Scully C. Recording by the police of violent offences; an accident and emergency departmen perspective. Med Sci Law 1989;29:251-7.

11 Langan PA, Farrington DP. Crime and justice in the United States and in England and Wales, 1981-96. Washington, DC US Department of Justice, 1998.

12 Crime and Disorder Act 1998. London: HMSO, 1998. 